\title{
The spatial effects of trade openness: a survey
}

\author{
Marius Brülhart
}

Published online: 16 December 2010

(C) Kiel Institute 2010

\begin{abstract}
This paper surveys the literature on the implications of trade liberalisation for intra-national economic geographies. Three results stand out. First, neither urban systems models nor new economic geography models imply a robust prediction for the impact of trade openness on spatial concentration. Whether trade promotes concentration or dispersion depends on subtle modelling choices among which it is impossible to adjudicate a priori. Second, empirical evidence mirrors the theoretical indeterminacy: a majority of cross-country studies find no significant effect of openness on urban concentration or regional inequality. Third, the available models predict that, other things equal, regions with inherently less costly access to foreign markets, such as border or port regions, stand to reap the largest gains from trade liberalisation. This prediction is confirmed by the available evidence. Whether trade liberalisation raises or lowers regional inequality therefore depends on each country's specific geography.
\end{abstract}

Keywords Trade liberalisation - Regional inequality · Agglomeration · Urban systems

JEL Classification $F 1 \cdot R 1$

\footnotetext{
M. Brülhart ( $\bowtie)$

Département d'économétrie et économie politique (DEEP),

École des HEC, Université de Lausanne, 1015 Lausanne, Switzerland

e-mail: Marius.Brulhart@unil.ch

M. Brülhart

Centre for Economic Policy Research (CEPR), London, UK
} 


\section{Introduction}

Trade economists have long studied what happens within countries when trade barriers are removed between countries. By far the most attention has been paid to the sectoral dimension of this problem. Theories of comparative advantage are all about how the market reallocates resources across industries and production factors to reap the gains from international specialisation. More recently, the focus has shifted from sectors to firms, with theories of intra-industry trade and heterogeneous firms shedding light on how trade affects distributions of firm types within countries.

I focus on a third dimension of within-country adjustment to trade: space. The importance of this issue is well understood by policy makers. An oft-heard fear related to trade liberalisation is that it could accentuate intra-national inequalities not only across industries and occupational groups but also across regions. Take the following quote from the 2009 World Development Report:

"The openness to trade and capital flows that makes markets more global also
makes subnational disparities in income larger and persist for longer in today's
developing countries. Not all parts of a country are suited for accessing world
markets, and coastal and economically dense places do better. China's GDP
per capita in 2007 was he same as that of Britain in 1911. Shanghai, China's
leading area, today has a GDP per capita the same as Britain in 1988, while
lagging Guizhou is closer to Britain in 1930. China's size, the openness of
coastal China to world trade, and Shanghai's location are the reasons (World
Bank 2008, p. 12)".

This quote is representative of mainstream economic thinking in so far as it makes two central assertions: that trade liberalisation increases within-country spatial inequality, and that it favours regions with better access to international trade routes. My aim is to test these two common claims against the insights from the relevant scientific literature.

Policy makers cannot ignore the spatial implications of international trade, if indeed they turn out to be a general corollary of open markets. In the European Union, for instance, redistributive regional policies have formed part and parcel of the post-war integration project since its very inception. While in reality these policies may chiefly be the result of political horse-trading, their intellectual underpinning is invariably provided by the claim that integration may harm "peripheral" or "disadvantaged" areas. Is this is a valid intellectual case? If it were, i.e. if trade systematically favoured regional divergence within countries, then accompanying regional policies such as those adopted in Europe might fruitfully be considered elsewhere too.

The last two decades have seen a resurgence of research interest in economic geography, and significant advances have been made in terms of scientific rigour and data availability. This is therefore a propitious moment to take stock of what this research teaches us about the effects of trade liberalisation on intra-national economic geographies. This survey covers both theoretical and empirical analyses, in an attempt to give as comprehensive as possible an overview of the current state 
of the relevant economic research. "Trade liberalisation" is understood primarily as the opening of cross-border goods markets through policy changes or technological improvements, but I also consider some papers that explore the effects of liberalised cross-border investment flows. ${ }^{1}$

The paper has a simple structure. Section 2 summarises relevant theoretical work, and Sect. 3 presents corresponding empirical evidence. Section 4 concludes.

\section{Theory}

Even though the spatial dimension of intra-national trade adjustment has attracted a fraction of the attention that international economists have dedicated to the sector and firm dimensions, the existing literature does offer a number of useful models that lend structure and rigour to the analysis of the regional question. The theoretical exercise undertaken in these papers is simple: they track what happens to the allocation economic activity across different regions within a country as trade with the rest of the world becomes less costly. This thought experiment abstracts from simultaneous changes in intra-national trade costs by assuming that within-country trade costs do not change, and that they are either zero or significantly lower than between-country trade costs.

This literature essentially consists of two generations of models: a somewhat older "urban systems" approach, based on perfectly competitive perfectly markets with exogenous region-level scale economies, and the more recent "new economic geography" (NEG) approach, which allows for monopolistically competitive markets and endogenises regional scale economies. Another distinction is between models that assume locations within countries to be ex ante identical, and models that assume these locations to differ in some inherent characteristics. I subdivide this section chronologically, treating the second distinction within each generation of models.

\subsection{Urban systems}

\subsubsection{Uniform intra-national space}

It took a long time for trade theory to incorporate the intra-national spatial dimension. To the best of my knowledge, the first general-equilibrium model of external trade and internal geography is due to Henderson (1982). This paper has pioneered the analysis of city distributions in (small) open economies.

Based on his seminal model of urban systems (Henderson 1974), Henderson (1982) develops a model of city size distributions in the neoclassical tradition: firms produce with constant returns to scale, goods are homogeneous, and goods and workers are perfectly mobile within a country. The distinctive twist of this model

\footnotetext{
1 This survey is of a qualitative nature, as a formal meta analysis would not yet be appropriate in view of the limited number and methodological heterogeneity of available empirical studies (see Tables 1, 2 in Sect. 3).
} 
relative to standard neoclassical trade theories is that city-level scale economies exist. These scale economies are external to individual firms, allowing perfect competition to prevail. They are modelled on the supply side as Hicks-neutral sector-specific productivity advantages of larger industrial clusters. Offsetting this productivity advantage is a demand-side congestion parameter, capturing the (assumed) inconveniences of big-city life. ${ }^{2}$ An additional dispersion force comes from the assumption that cities are monocentric, and that larger cities therefore spend more of their workers' resources on commuting. Apart from their size, cities differ in terms of their relative use of labour and capital in production, and therefore in terms of their sectoral specialisation. In equilibrium, every city is perfectly specialised in the production of one traded good as well as non-traded "housing". 3 Abstraction is made of differences in endowments and amenities, and yet cities of different sizes and sectoral specialisations coexist in equilibrium. Equilibrium city sizes increase with the degree of scale economies, with the capital intensity of production and with the overall size of the industry in which a city is specialised.

Henderson's (1982) main result is to show that the fundamental theorems of neoclassical trade theory hold equally in his urban-systems model, assuming a small open economy. What does this imply for the research question that motivates this survey? Three implications can be highlighted:

- Since the model assumes that all workers are perfectly mobile, equilibrium real wages (expressed in utility terms) are always equalised across cities. International trade liberalisation, even though it will affect the distribution of city sizes, will have no regional distributive effects in welfare terms.

- Import restrictions increase the number of cities that are specialised in the protected industries. Protectionism therefore has spatial effects. If import barriers are applied to big-city industries, protectionism raises urban concentration.

- The Heckscher-Ohlin and Rybczynski theorems imply that trade liberalisation will increase the number of cities that are specialised in a capital-intensive good if the country as a whole is relatively capital abundant, and of cities that are specialised in a labour-intensive good if the country as a whole is relatively labour abundant. Since capital-intensive cities are larger in Henderson's model, this implies that trade liberalisation will lead to a shift from smaller to larger cities in capital-abundant countries, and from larger to smaller cities in labourabundant countries. Therefore, the effect of trade on urban concentration depends on countries' relative factor endowments.

In a similar model featuring industries with firm-level increasing returns, Rauch (1989) finds that countries with lower commuting costs (i.e. cheaper means of sustaining large cities) will have a comparative advantage in increasing-returns industries (which operate most efficiently in large cities). The intuitive implication

\footnotetext{
${ }^{2}$ Henderson (1987) does away with demand-side congestion and, by choosing a specific a functional form for the supply-side scale-economy term, arrives at the same results with regard to trade openness as Henderson (1982).

${ }^{3}$ Cities being perfectly specialised implies that city-level increasing returns can be thought of in this model as own-sector "localisation economies".
} 
is that trade liberalisation will lead to urban concentration in countries where large cities are cheaper to sustain-be it due to conductive topography, to weaker planning restrictions or to the efficiency of local public services.

\subsubsection{Heterogeneous intra-national space}

Models of international trade that represent intra-national geography as intrinsically featureless miss one key element of reality: within a given country, some places enjoy better access to international markets than others. The larger a country and the more diverse it is in terms of topography and infrastructure, the more such differential market access will matter. In the words of Henderson (1996, p. 33), "the impact of trade is situation-specific, depending on the precise geography of the country".

This aspect was first modelled formally by Rauch (1991). He develops a multisector Ricardian trade model with an internal geography consisting of monocentric cities as in Henderson $(1974,1982) .{ }^{4}$ He adds a twist by imposing a specific structure on this internal geography. Internal trade costs are assumed to exist (in iceberg form), and cities are located in a straight line (a "river") that is perpendicular to the country's border (the "coast"). Hence, a natural ranking arises among potential urban sites in terms of their access to foreign markets, with cities located close to the coast facing lower international trade costs than interior cities.

In autarky, i.e. with prohibitively high external trade costs, the location of cities is without consequence, and all cities are of equal size in equilibrium. At intermediate trade costs, some cities near the border partly specialise and engage in international trade, while other cities further inland remain autarkic. The trading cities will then be monotonically bigger the closer they are located to the coast, while the interior non-trading cities will be equally sized. If international trade costs are low enough (but internal trade costs remain unchanged), even the most inland city will specialise and engage in international trade, and city sizes will decrease monotonically with distance from the coast for all cities.

The implication of the Rauch (1991) model is straightforward: external trade liberalisation with unchanged intra-national trade costs will favour the growth of cities close to the coast (or border) and, absent any other geographical features, bring about a monotonic city-size gradient as one moves inland. Hence, trade opening is associated with increasing urban concentration, and with a shift of population towards cities with better access to foreign markets.

Note that this gradient concerns city sizes only; since workers are assumed to be fully mobile across cities, real wages are equalised across cities, and the issue of spatial inequality again does not arise. This invariance of real wages is common to all pre-NEG general-equilibrium models. Hence, taken literally, the trade-induced spatial effects in pre-NEG models are of interest only to map makers but not policy

\footnotetext{
4 One difference to Henderson's model is that Rauch (1991) assumes agglomeration externalities to arise on the demand side, through consumers deriving pleasure from interacting with each other while working or shopping in the city centre. As these externalities are not specific to individual sectors, they can be considered a form of urbanisation economies.
} 
makers, as the changing internal geographies in these models are not associated with any welfare-relevant spatial inequalities.

\subsection{New economic geography}

\subsubsection{Uniform intra-national space}

Building on the seminal paper by Krugman (1991), Krugman and Livas Elizondo (1996) were first to study regional adjustment to international trade liberalisation in a NEG model. Unlike the urban-systems models following Henderson (1974), where the number and size of cities is endogenous, the NEG framework exogenously partitions countries into regions. ${ }^{5}$ In the Krugman and Livas Elizondo (1996) model, there are two such regions, one factor of production and one industry, consisting of horizontally differentiated goods. Their model remains close to Henderson's framework in so far as it represents regions as monocentric cities, where the need to commute acts as a monotonically increasingly cost of city size. The main difference is that external economies are now micro-founded: because of a taste for variety and interregional iceberg transport costs, consumers like to locate close to as large a number of producers as possible ("forward linkages"); and in order to save on transport and fixed set-up costs, monopolistically competitive producers seek to locate their single plant as close to their consumers as possible ("backward linkages").

To this two-region domestic economy, Krugman and Livas Elizondo (1996) add a third region, the "rest of the world". The two domestic regions are identical in every respect, including access to the rest of the world. In this sense, this is a model of uniform intra-national space. ${ }^{6}$

The model lends itself to the comparative static examination of trade liberalisation: the trade cost between the two domestic regions and the rest of the world is gradually lowered, while the internal trade cost remains unchanged at a comparatively low level. While the model cannot be solved analytically, simulations produce a stark picture: if parameters are such that autarkic economies are spatially concentrated, then trade liberalisation favours the internal dispersion of activities. The mechanism underlying this result is as follows. At high external trade costs, imports and exports are relatively unimportant to the location choices of firms and consumers, and domestic backward and forward linkages fully come into play. This favours agglomeration in one of the two domestic regions. At low external trade costs, however, a large share of goods are bought from and sold to abroad. Given the assumed equality of both regions' access to the foreign market, firms and consumers are indifferent between the two domestic regions with respect to internationally traded goods. Hence, as trade openness increases, the weight of domestic backward and forward linkages is reduced. The strength of congestion

\footnotetext{
5 On the differences between neoclassical urban systems models and NEG models, see Henderson (1996).

6 Alonso Villar (2001) simulates the Krugman and Livas Elizondo (1996) model for a two-region home country and two symmetric one-region foreign countries $(1+2+1)$ and obtains qualitatively the same result: trade liberalisation favours internal dispersion.
} 
costs, however, is modelled in a way that makes it independent of the external trade costs. Hence there can be a threshold of trade openness beyond which the congestion force comes to dominate the backward and forward linkages, and population will evenly disperse among the two regions. ${ }^{7}$ Krugman and Livas Elizondo (1996, 137) frame their model in a developing-country context and interpret it rather forcefully, by concluding that "the giant Third World metropolis is an unintended by-product of import-substitution policies, and will tend to shrink as developing countries liberalise".

An alternative version of the same story is provided by the model of Behrens et al. (2007). In this model too, external trade liberalisation favours internal dispersion. The framework within which this effect is found, however, differs from that of Krugman and Livas Elizondo (1996). Behrens et al. (2007) use the model of monopolistic competition due to Ottaviano et al. (2002), which can be solved analytically and allows for welfare analysis. They look at a world consisting of two identical countries, each containing two symmetric regions. Instead of the urban congestion costs assumed by Krugman and Livas Elizondo (1996), their model contains two other dispersion forces. One dispersion force arises from the assumption that some workers ("farmers") are immobile across regions. This is the dispersion force of the original Krugman (1991) model. In addition, the Ottaviano et al. (2002) model features markups that fall in the intensity of local competition. This "competition effect" in regions with high firm concentrations acts as another dispersion force. The resulting pattern in the Behrens et al. (2007) model, mirrors that of Krugman and Livas Elizondo (1996): external trade liberalisation, with unchanged internal transport costs, favours internal dispersion. ${ }^{8}$ Since dispersion is associated in this model with higher welfare, the centrifugal impact of trade liberalisation on internal economic geographies turns out to be desirable.

Interestingly, a number of apparently very similar models arrive at exactly the reverse result, whereby trade liberalisation fosters intra-national agglomeration rather than dispersion. These models are in fact closer to the original Krugman (1991) NEG model than both Krugman and Livas Elizondo (1996) and Behrens et al. (2007), as they do not introduce urban congestion costs and they rely on the original Dixit-Stiglitz representation of preferences. The first papers in that line of research were Monfort and Nicolini (2000) and Monfort and van Ypersele (2003), analysing trade integration between two two-region countries $(2+2)$, and Paluzie (2001), looking at a two-region country liberalising with respect to a one-region "rest of the world" $(2+1)$. Their simulation results tell a consistent story: external liberalisation fosters internal agglomeration.

\footnotetext{
7 There also exists an interval at intermediate levels of the external trade cost for which both dispersion and concentration are locally stable equilibria.

8 Another interesting result in Behrens et al. (2007) is that the spatial allocation of mobile activities within a country is not affected by that same spatial allocation in the other country. In that sense, internal geographies are mutually independent. However, in that same model, one country's internal geography matters for the other country's welfare (through price effects). Moreover, in a closely related paper (Behrens et al. 2006), the same authors show that if international trade costs fall more than proportionally with trade volumes, internal economic geographies become interdependent.
} 
Another exercise in the same vein is the analysis of Fujita et al. (1999, chap. 18). They add a sectoral dimension to the Krugman-Livas Elizondo (1996) model. Assuming the existence of sector-level agglomeration forces (from input-output linkages) but no sector-level dispersion forces, they find that trade liberalisation triggers geographic concentration of individual sectors. Further comparable simulation analyses are reported by Brülhart et al. (2004) and by Crozet and Koenig (2004) for a $2+1$ world. $^{9}$ Both papers also find that external trade liberalisation triggers internal spatial concentration when domestic regions are identical ex ante.

Whence the difference between the two types of model? As is typical of NEG frameworks, all models predict that the intensity of agglomeration forces falls with trade liberalisation. The question then is what happens to dispersion forces. ${ }^{10}$ In the seminal paper by Krugman (1991), the intensity of the dispersion force implied by the demand of spatially immobile "farmers" falls even faster than the that of the agglomeration force, implying that trade liberalisation, once it exceeds some threshold value, induces agglomeration. ${ }^{11}$ This mechanism drives the results of Monfort and Nicolini (2000) and Paluzie (2001). In order to reverse these results, the earlier papers had to assume stronger dispersion forces, either in the form of exogenous urban congestion costs (Krugman and Livas Elizondo 1996) or in the form of lower markups in denser regions (Behrens et al. 2007).

Which type of model is better? Both approaches rely on specific functional forms, and no a priori reasoning will be able to adjudicate between the two. The only viable solution would appear to be empirical. If the data were to point to external liberalisation systematically triggering internal dispersion, then the models with strong dispersion forces would appear as better representations of reality. Otherwise, the models with weaker dispersion forces would seem more useful.

\subsubsection{Heterogeneous intra-national space}

One step towards greater realism is to allow for inherently different regions, the key consideration being that some places offer cheaper access to foreign markets than others.

This issue was first explicitly considered within a NEG framework by Alonso Villar (1999), who applied the model of Krugman and Livas Elizondo (1996) to a

\footnotetext{
9 The former paper is based on the Pflüger (2004) variant of the NEG model, which can be solved analytically and features smooth changes in spatial configurations rather than the discrete "catastrophes" inherent in the Krugman (1991) model, while the latter considers the original Krugman (1991) framework. This difference in modelling approaches turns out to have no effect on the qualitative predictions.

${ }^{10}$ The key difference between the papers discussed in this section concerns assumptions on dispersion forces. However, other elements of the model can be manipulated as well. For instance, Mansori (2003) assumes that there are region-specific fixed costs to international trade. This implies an additional agglomeration force, since with increasing importance of external trade, the price of access to foreign markets become relatively more important, which favours concentration in a single region. This can be thought of as the endogenous formation of a port region. Mansori (2003) finds that this assumption too can reverse the Krugman and Livas Elizondo (1996) result.

${ }^{11}$ See Baldwin et al. (2003, chap. 2) for an discussion of this mechanism.
} 
$1+3+1$ world, composed of two symmetric single-region outside countries and a home country consisting of three regions. The model's assumed structure of trade costs is as if the five countries/regions were placed on a line. Hence, of the three domestic regions, two border one of the two identical foreign countries; and one is the interior region, with equally costly access to both foreign markets. Alonso Villar (1999) finds that for large enough outside countries and non-prohibitive international trade costs, agglomeration of mobile activity in the interior region cannot be an equilibrium. Instead, one or both border regions become host to all mobile activity. This model thus suggests that border regions have a locational advantage in open economies.

Alonso Villar (1999) does not explicitly trace what happens to domestic spatial equilibria as external trade costs are gradually lowered. This is done in Brülhart et al. (2004) and Crozet and Koenig (2004), for a $2+1$ world. They find two particular features of the asymmetric model compared to the version with uniform intra-national space. First, as foreign demand weakens the domestic agglomeration force, an additional effect appears, because domestic firms now have an incentive to locate in the region closest to the foreign market. One of the potential effects of trade liberalisation is thus to attract domestic firms towards the border, where they can reap the full benefit of improved access to foreign demand. Second, as foreign supply weakens the domestic dispersion force, the interior region allows firms to locate away from the foreign competitors. Hence, trade liberalisation may attract domestic firms towards the interior region, where they are relatively sheltered from foreign competition. The analysis shows that if the interior region hosts the locus of agglomeration prior to trade liberalisation, mobile activity may not relocate towards the border region even if trade becomes free. A relocation towards the border region becomes more probable (a) the larger is the share of mobile activity in the border region prior to liberalisation, (b) the stronger is the degree of liberalisation, (c) the larger is the size of the foreign market, and (d) the more complementary is the sectoral composition of the foreign market (such that the demand pull towards the border is strong, and the competition effect is weak).

Finally, real-world regions differ in more respects than access to foreign markets. Unequal factor endowments are an evident dimension to consider. Haaparanta (1998) does just that, by studying a two-country two-region model $(2+2)$ where, within each country, each region is uniquely endowed with one of two specific production factors, such that each traded good is produced only by one type of region. Other than that, the model is standard NEG. Trade liberalisation in this model leads to spatial concentration in the region that produces the good for which the country as a whole enjoys a comparative advantage. Hence, quite intuitively, if industries are exogenously tied to certain regions, specialisation in comparativeadvantage industries will lead to spatial concentration in the regions that host these industries, and this process can be reinforced by agglomeration economies.

The broad implications of NEG models closely resemble those of the pre-NEG literature: whether trade liberalisation favours overall intra-national concentration or dispersion depends on possibly quite subtle, in general equally tenable, modelling choices; whereas the tendency for trade liberalisation to favour re-location towards border regions emerges as an almost ubiquitous result. The two approaches do, 
however, differ in terms of the implied distributive, effects. In neoclassical models, real wages are equalised across regions, and changes in the geography of production are therefore not associated with regional inequality. This is also true for interior equilibria in NEG models, where mobile activity does not fully agglomerate in one place and real wages therefore equate across regions. In the fully agglomerated equilibria, however, the residents of the region that hosts the agglomeration enjoy higher real wages than the (immobile) residents of the depleted "periphery". Hence, trade liberalisation has the potential to make regions with better access to foreign markets better off while implying a net reduction in welfare for the (immobile residents of the) remaining regions.

The impact of trade liberalisation on overall national welfare also appears in a different light in NEG compared to neoclassical approaches. The three theoretical studies that consider this issue explicitly all conclude that, with agglomeration effects, trade liberalisation can be welfare reducing (Haaparanta 1998; Mansori 2003; Behrens et al. 2007). The three models differ in many respects, but all of them feature market equilibria with excess agglomeration. In other words, all three models imply a rationale for regional policy counteracting agglomeration tendencies as trade is liberalised. However, one would not do justice to this literature to read such a simple policy prescription into it. Trade-induced welfare-reducing agglomeration is an interesting but special case, and welfare-improving trade liberalisation remains possible in all these models. ${ }^{12}$

\section{Empirical evidence}

Similar to the distinction in theory between models that do not consider intranational regional heterogeneity and models that do, one can categorise empirical studies into those that explore the determinants of summary measures of withincountry spatial concentration and those that study specific geographic reallocations within individual countries. This chapter is therefore subdivided according to whether statistical identification is derived from between-country variation or from within-country variation. ${ }^{13}$

\subsection{Cross-country regressions}

Table 1 presents a chronological summary of studies that in one way or another regress some measure of within-country spatial concentration on a set of explanatory variables that includes a measure of trade openness. The differences in data coverage, definition of variables, regression specification and estimation technique are large-too large in fact for a formal meta-analysis. A majority of

\footnotetext{
12 In addition, these models are static in nature. As shown by Bertinelli and Black (2004), agglomerations that appear excessively large in a static sense may in fact be optimal dynamically, if growth is knowledgedriven and knowledge is generated in agglomerations.

13 I consider only studies that use regression techniques to identify the spatial effects of openness.
} 


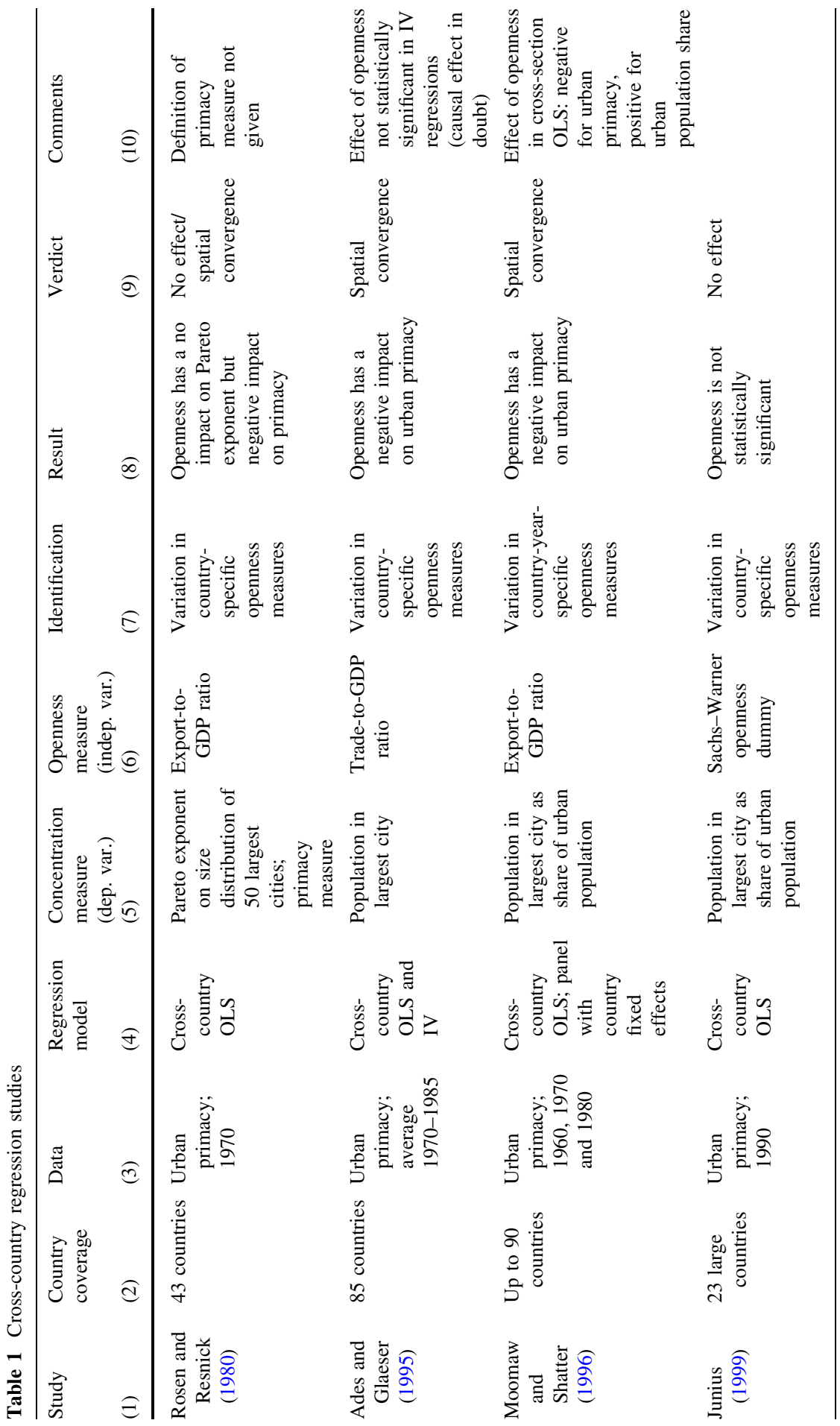




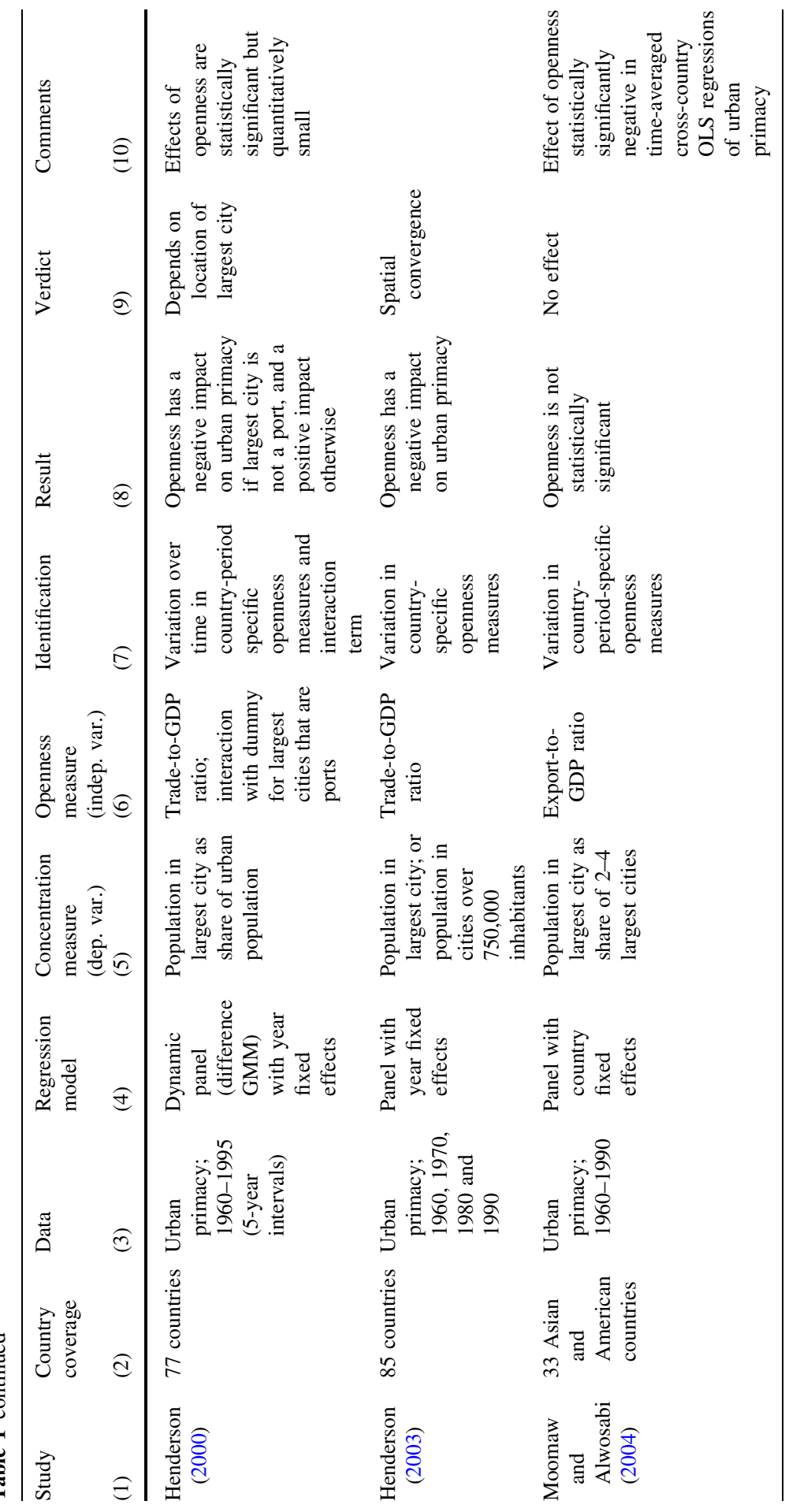




\begin{tabular}{|c|c|c|c|c|}
\hline & $\stackrel{\varrho}{\ominus}$ & 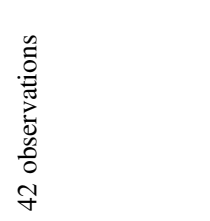 & 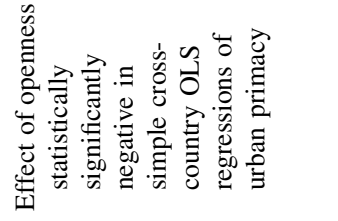 & 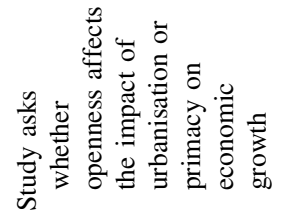 \\
\hline$\frac{\bar{U}}{\frac{\overrightarrow{0}}{0}}$ & $\widehat{(})$ & 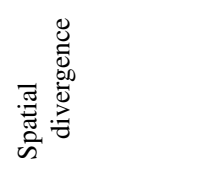 & 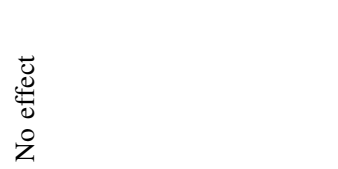 & 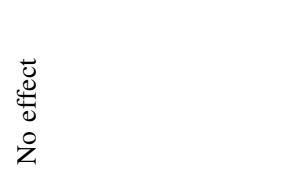 \\
\hline 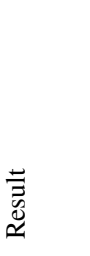 & क् & 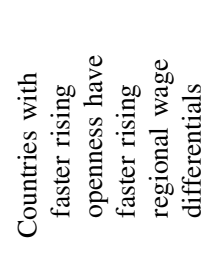 & 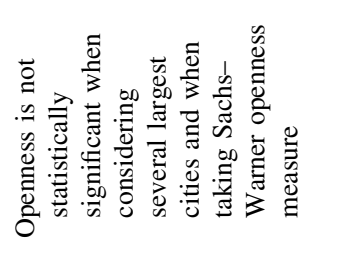 & 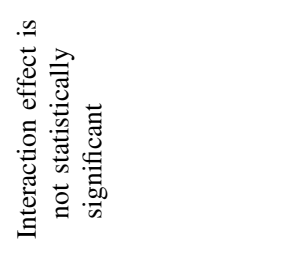 \\
\hline 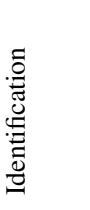 & $E$ & 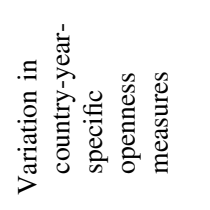 & 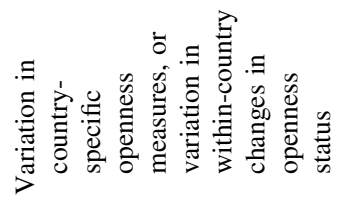 & 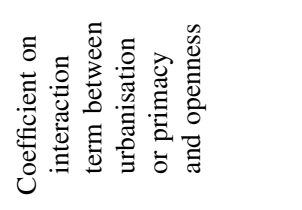 \\
\hline 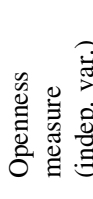 & & 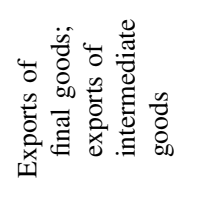 & 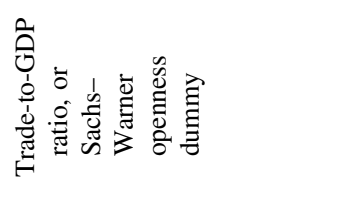 & 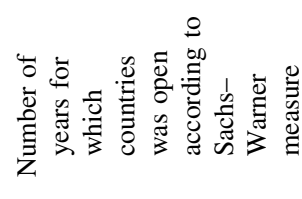 \\
\hline 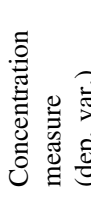 & & 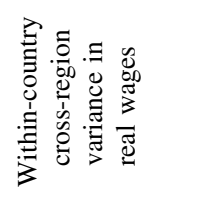 & 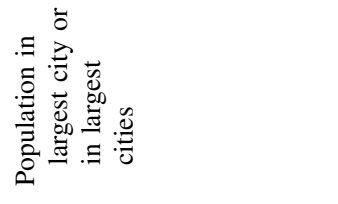 & 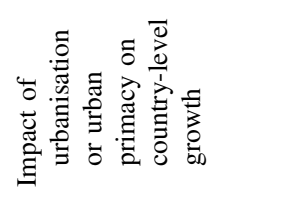 \\
\hline 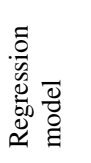 & 尹્犬 & 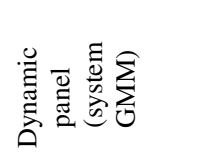 & 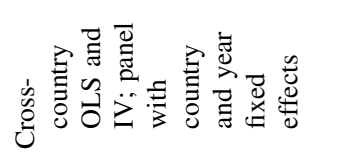 & 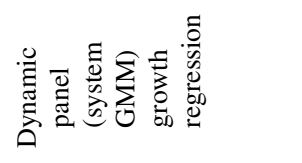 \\
\hline صّ & $\widehat{(0)}$ & 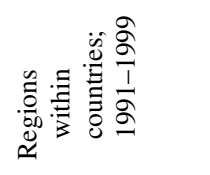 & 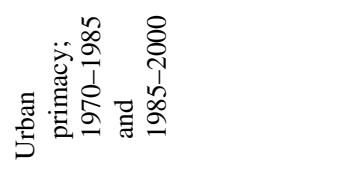 & 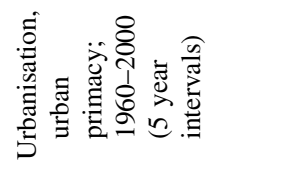 \\
\hline 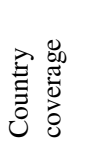 & $\widehat{d}$ & 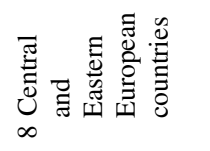 & $\stackrel{\stackrel{\mathscr{Q}}{\Xi}}{\stackrel{\Xi}{\Xi}}$ & 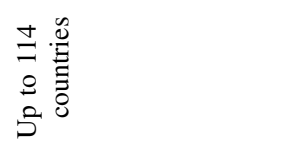 \\
\hline 量 & 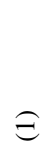 & 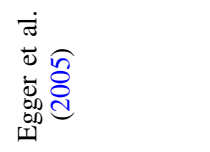 & 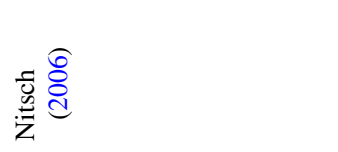 & 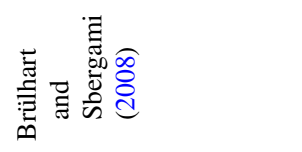 \\
\hline
\end{tabular}




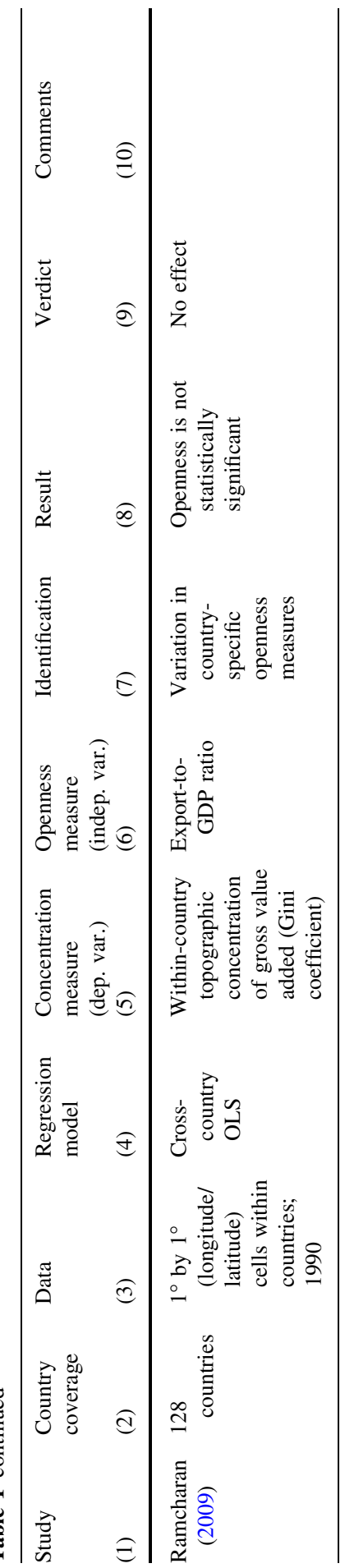


studies use data on the shape of city-size distributions as the measure of spatial concentration.

Column (9) of Table 1 brings out a remarkably consistent and perhaps surprising regularity: ten out of the eleven studies find that trade openness either has no statistically significant effect on within-country concentration, or that it is associated with spatial convergence. The available evidence therefore cannot be said to support the view that trade liberalisation systematically fosters within-country regional divergence-in fact the opposite view would seem to get rather stronger support.

I shall not discuss each of the eleven papers covered by Table 1, but focus on four of them that are of particular relevance. First, the outlier: the study by Egger et al. (2005) is unique in associating trade openness with spatial divergence. Their dependent variable is the variance of regional real wages within countries. Thus, theirs is the only study of Table 1 that employs a measure of differentials in factor prices (wages) rather than factor quantities (population) as the dependent variable. Taken at face value, this could be interpreted as suggesting that trade induces significant within-country divergence in real wages without corresponding labour movements. It is also possible, however, that they pick up a specificity of Central and Eastern European transition countries in the 1990s. The size of their sample (42 observations) also suggests that some caution should be applied in inferring general conclusions.

The most cited of the papers covered by Table 1 is Ades and Glaeser (1995). They were first to run large cross-country regressions seeking to explain determinants of urban primacy, defined as the population share of a country's largest city. The negative and statistically significant effect of openness found in simple OLS regressions turns insignificant once they take account of the possibility of reverse causality by instrumenting the openness variable. They therefore conclude that the "hypothesis that urban concentration is negatively related to international trade is borne out in the data. [...] However, [the] instrumentalvariables results cast doubt on the causality in these correlations" (p. 224).

Nitsch (2006) updates the Ades-Glaeser study with a larger country sample. His data are longitudinal, allowing him to include country fixed effects and thereby to purge the regression model of potential country-specific omitted variable bias. He finds no statistically significant effect of various openness measures on urban primacy in any of his panel regressions. Similarly, Brülhart and Sbergami (2008), drawing on an even larger cross-country data set, find that the interaction of openness and urban concentration is never statistically significant in dynamic panel growth regressions. This implies that the (on average positive) impact of urbanisation on economic growth is independent of openness, as is the (on average negative) impact of urban primacy. It conversely also implies that the (on average positive) impact of openness on economic growth is independent of urban concentration. Hence, it does not seem that more open countries benefit less or suffer more from concentrated urban geographies than less open countries do.

The standard empirical specification is a regression of some measure of geographic concentration, typically urban primacy, and a set of explanatory variables that includes trade openness. Henderson (2000) proposes a simple but interesting extension of this design, by including an interaction term between trade 
openness and a dummy that is equal to one if the country's largest city has a sea port. While the effects he estimates are quantitatively rather modest, he does find statistically significant evidence that, overall, openness reduces urban primacy, but that, if the largest city is a port, openness increases primacy. ${ }^{14}$ This finding suggests that, in empirics just as in theory, an assessment of the intra-national spatial effect of trade liberalisation needs to account for the heterogeneity of intra-national space. I now turn to studies which do just that.

\subsection{Within-country regressions}

Except for Henderson (2000), between-country econometric studies do not control for different intra-national geographies. There exists, however, a growing literature that focuses on heterogeneous regional responses to trade liberalisation within a given country. A summary of this literature is provided in Table 2.

Just as in Table 1, column (9) of Table 2 is an attempt at summarising the key result of each paper by attributing it to one of three categories: trade openness favours spatial convergence, it favours spatial divergence, or it has no discernible effect. Only one of the papers covered in Table 1 fell into the "spatial divergence" category. The picture is much more mixed in the case of within-country studies. Table 2, column (9), shows that seven of the 14 papers associate trade opening with spatial divergence, whereas three papers diagnose spatial convergence.

Why this difference? One reason is that one country, Mexico, has attracted by far the most scientific research on this issue. Seven of the 14 papers covered in Table 2 are based on Mexican data. Mexico indeed represents an interesting case, given its historic inward-orientation followed by rapid trade liberalisation from the mid1980s onwards. The Mexican papers that allow a categorisation by "verdict" (Table 2, column 9) all point towards spatial divergence in the wake of trade liberalisation. The two original studies by Hanson $(1997,1998)$ hold the key to this result: trade liberalisation led to a shift of activity towards the Mexican border with the United States. Since these border regions were already relatively richer and more industrialised than the Mexican average prior to the opening of trade (see Hanson 1998), the boost they received from trade liberalisation implied an increase in measured nationwide regional inequality. ${ }^{15}$

Essentially the same story has been documented for a number of Asian countries. In China, trade appears to have disproportionately favoured the already-richer coastal regions (Kanbur and Zhang 2005). Henderson and Kuncoro (1996) report that the Indonesian trade liberalisation of 1983 was associated with a stronger

\footnotetext{
${ }^{14}$ In a survey of the literature, Duranton (2008) nevertheless concludes that the empirical support for trade-based explanations of urban primacy remains weaker than evidence pointing towards political and institutional factors that shape primacy.

15 Faber (2007) confirms that employment in export-oriented industries grew more strongly in Mexican border regions, but suggests that import-competing industries grew more strongly in interior regions. While this result turns out not to be robust to the timing of the trade variable, it does point towards trade liberalisation changing not only the spatial distribution of aggregate activity but also the sectoral composition of regions. Hanson (2001) furthermore documents how export-led growth of Mexican border towns promoted economic growth of adjacent US border towns, thus providing further evidence of the economic advantages enjoyed by border regions under trade liberalization.
} 


\begin{tabular}{|c|c|c|c|c|c|c|}
\hline & $\stackrel{\varrho}{\ominus}$ & 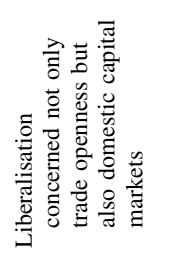 & 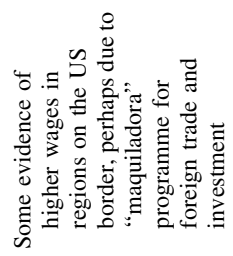 & 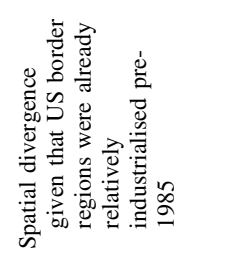 & 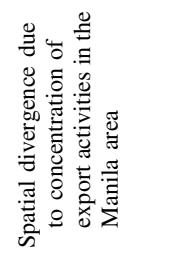 & 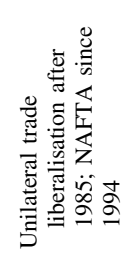 \\
\hline & $\widehat{\sigma}$ & 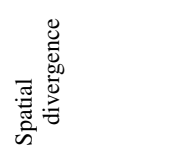 & 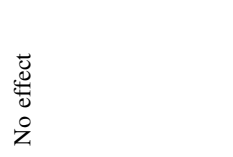 & 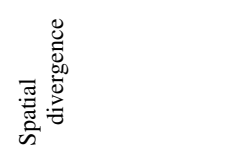 & 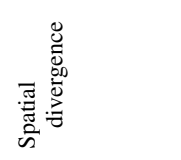 & 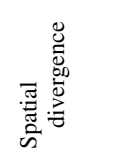 \\
\hline 或 & $\widehat{\infty}$ & 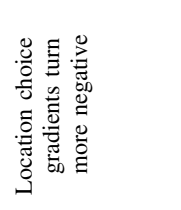 & 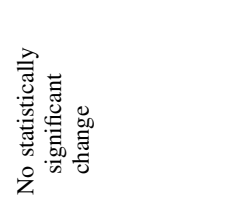 & 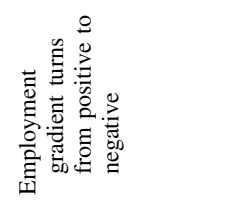 & 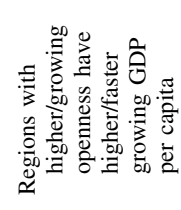 & 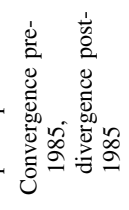 \\
\hline & $E$ & 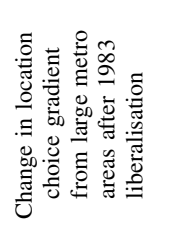 & 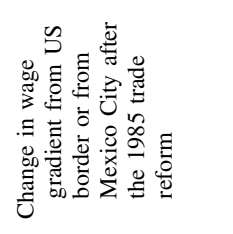 & 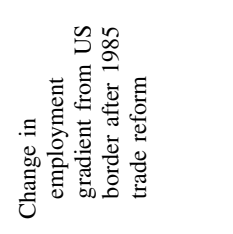 & 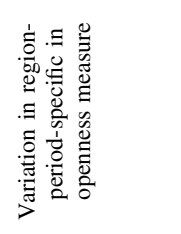 & 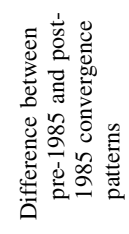 \\
\hline 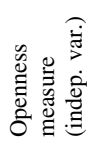 & & 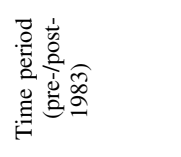 & 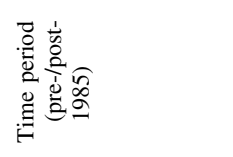 & 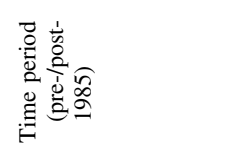 & 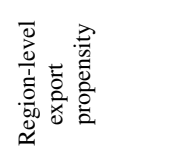 & 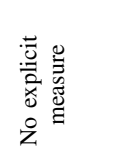 \\
\hline 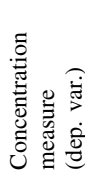 & & 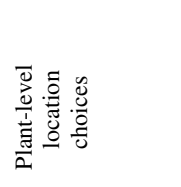 & 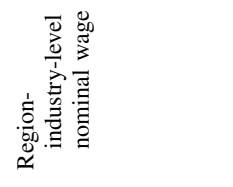 & 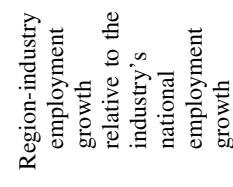 & 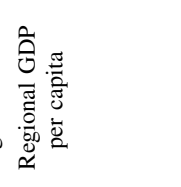 & 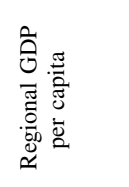 \\
\hline 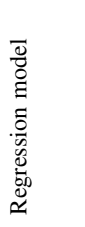 & 丹 & 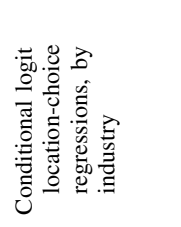 & 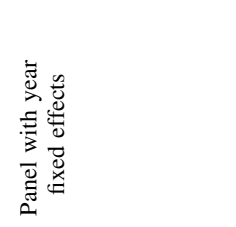 & 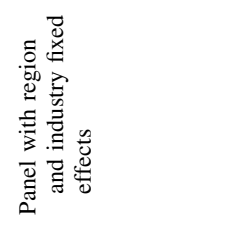 & 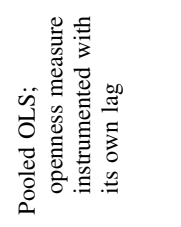 & 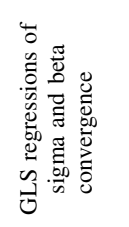 \\
\hline صّ & $\widehat{0}$ & 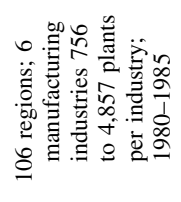 & 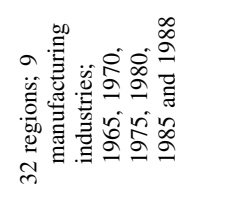 & 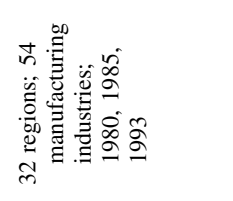 & 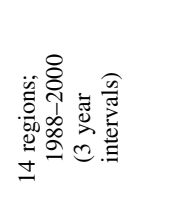 & 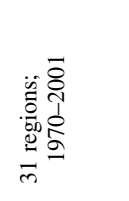 \\
\hline 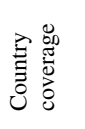 & $\widehat{d}$ & 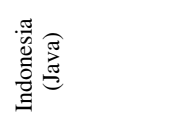 & $\begin{array}{l}\frac{8}{x} \\
\frac{0}{\Sigma}\end{array}$ & 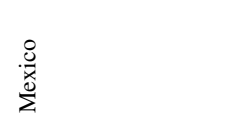 & 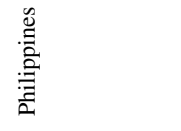 & $\frac{8}{\frac{8}{x}}$ \\
\hline$\vec{g}$ & 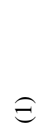 & 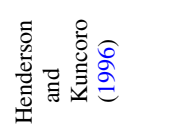 & $\begin{array}{l}\overline{0} \\
\text { 总 } \\
\text { 奇 }\end{array}$ & 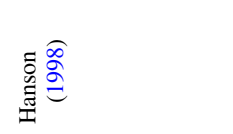 & 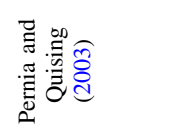 & 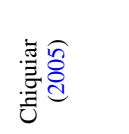 \\
\hline
\end{tabular}




\begin{tabular}{|c|c|c|c|c|c|}
\hline \multicolumn{2}{|c|}{ ठ을 } & \multicolumn{3}{|r|}{ 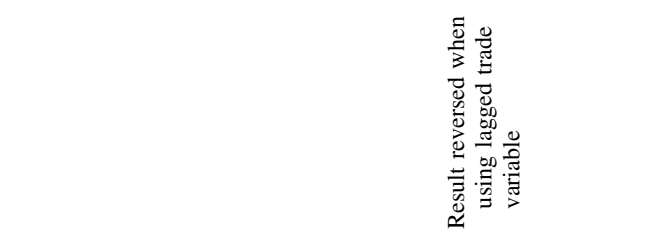 } & \multirow{2}{*}{ 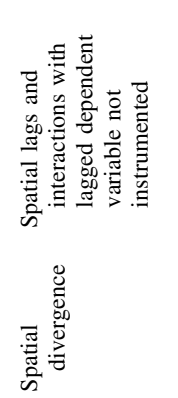 } \\
\hline 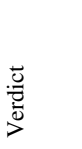 & $\hat{\sigma}$ & 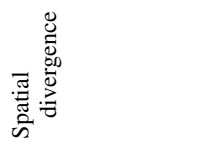 & 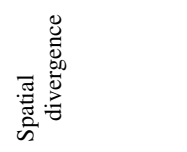 & 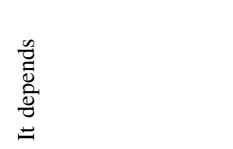 & \\
\hline 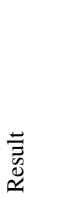 & $\widehat{\infty}$ & 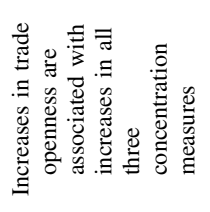 & 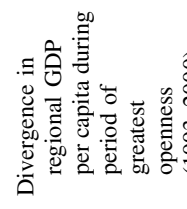 & 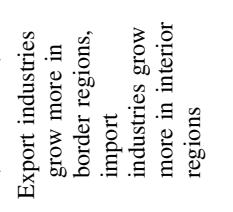 & 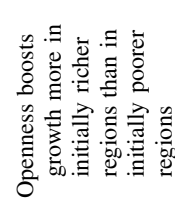 \\
\hline .0ّ & $E$ & 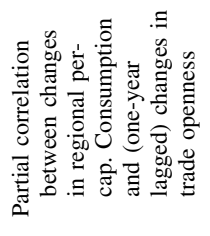 & 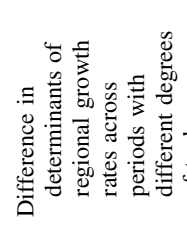 & 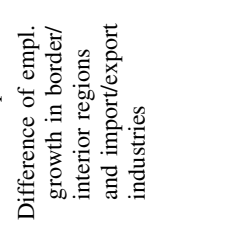 & 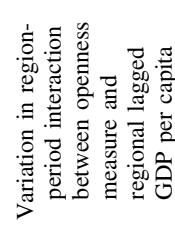 \\
\hline 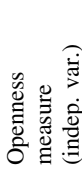 & & 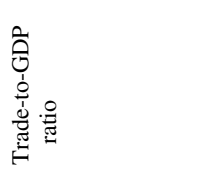 & 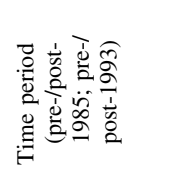 & 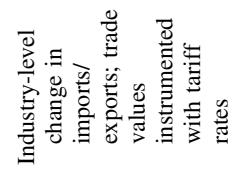 & 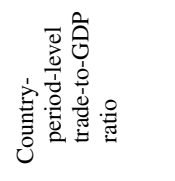 \\
\hline 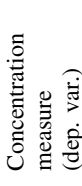 & & 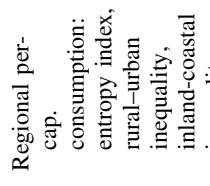 & 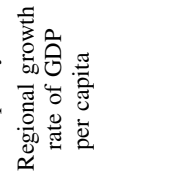 & 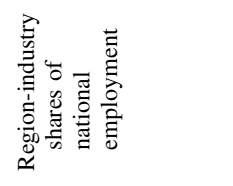 & 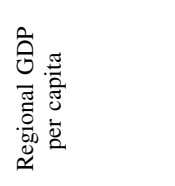 \\
\hline 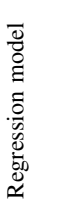 & $\underset{\Xi}{\mathcal{I}}$ & 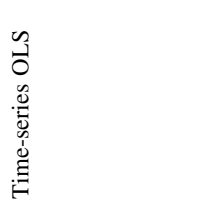 & $\begin{array}{l}0 \\
0 \\
0 \\
0 \\
0 \\
0 \\
0 \\
\vdots \\
0 \\
0 \\
0 \\
0\end{array}$ & 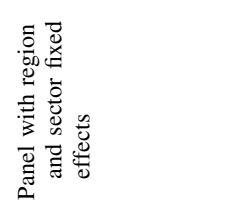 & 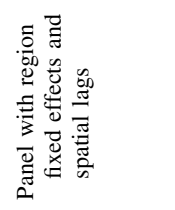 \\
\hline ڤँّ & $\widehat{0}$ & 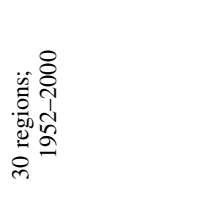 & 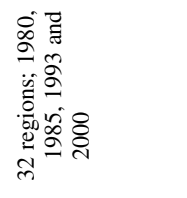 & 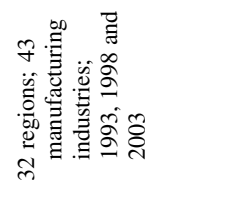 & 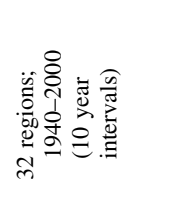 \\
\hline 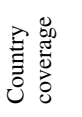 & $\widehat{d}$ & 苞 & $\frac{8}{\frac{3}{x}}$ & $\begin{array}{l}\frac{8}{x} \\
\frac{0}{\Sigma}\end{array}$ & $\frac{8}{\frac{8}{x}}$ \\
\hline 焉 & $\lesssim$ & 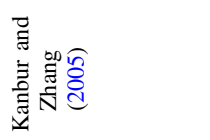 & 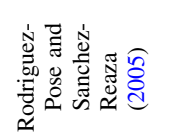 & 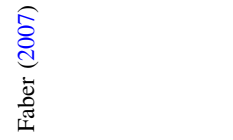 & 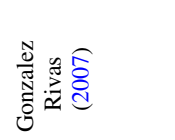 \\
\hline
\end{tabular}




\begin{tabular}{|c|c|c|c|c|c|c|}
\hline 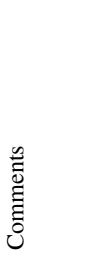 & $\stackrel{\varrho}{\varrho}$ & 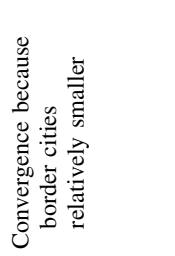 & 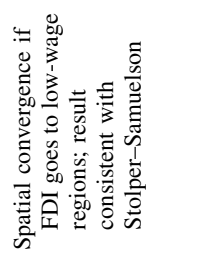 & & 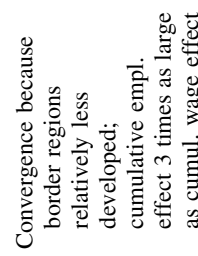 & 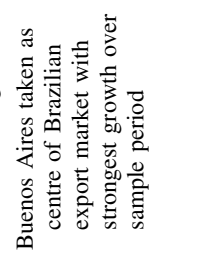 \\
\hline 总 & $\hat{\sigma}$ & 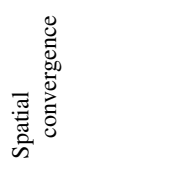 & $\begin{array}{l}\frac{n}{0} \\
\frac{0}{0} \\
\frac{0}{0} \\
=\end{array}$ & 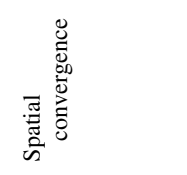 & 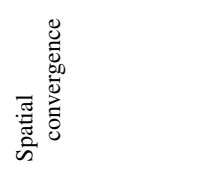 & $\begin{array}{l}y \\
\frac{y}{0} \\
\frac{0}{0} \\
=\end{array}$ \\
\hline 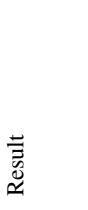 & $\widehat{\infty}$ & 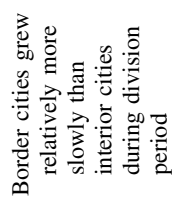 & 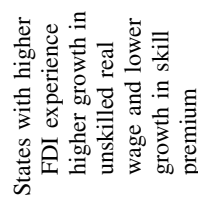 & 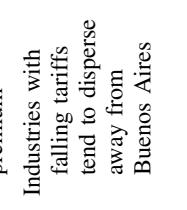 & 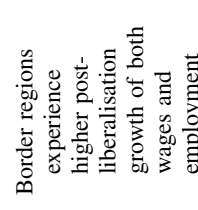 & 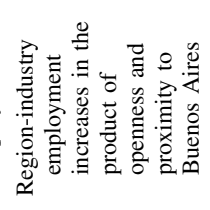 \\
\hline 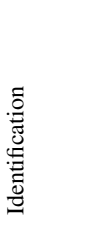 & $E$ & 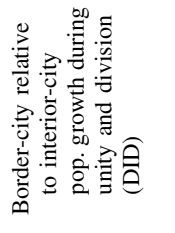 & 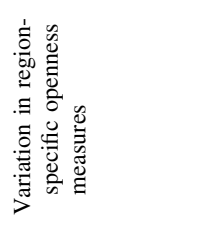 & 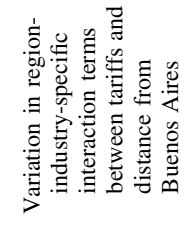 & 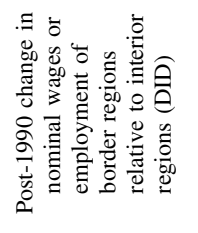 & 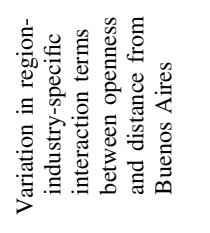 \\
\hline 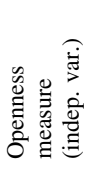 & 6 & 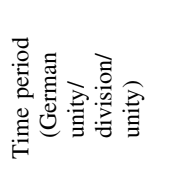 & 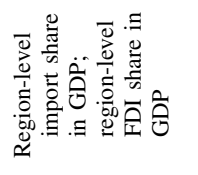 & 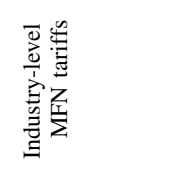 & 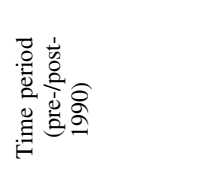 & 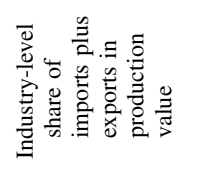 \\
\hline 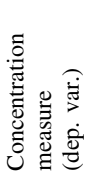 & & 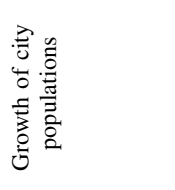 & 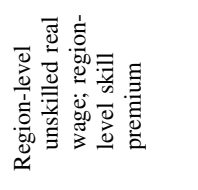 & 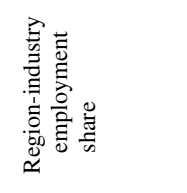 & 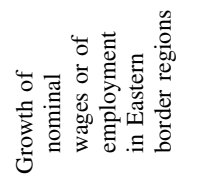 & 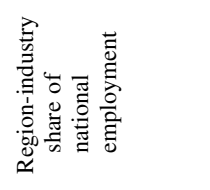 \\
\hline 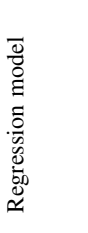 & Ð & 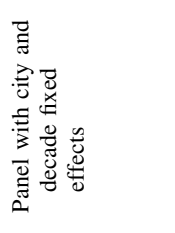 & 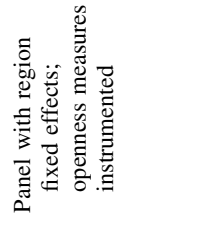 & 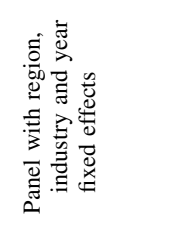 & 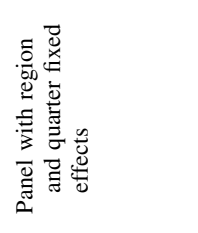 & 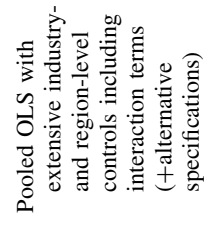 \\
\hline 卺 & $\widehat{(0)}$ & 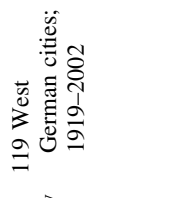 & 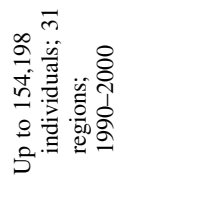 & 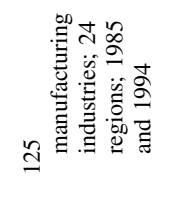 & 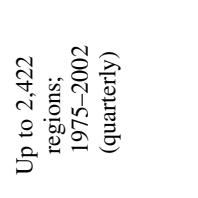 & 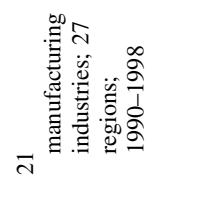 \\
\hline 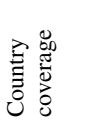 & $\widehat{d}$ & 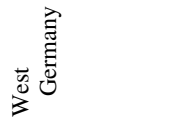 & 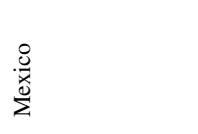 & 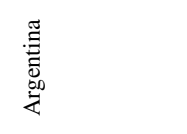 & 莺 & 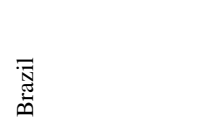 \\
\hline 量 & 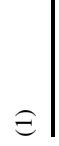 & 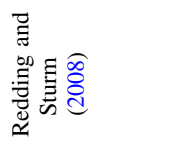 & 莺 & 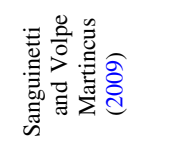 & 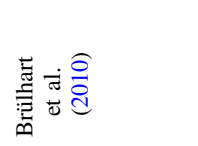 & 总施 \\
\hline
\end{tabular}


concentration of private sector firms in the main metropolitan areas of Java. ${ }^{16}$ In the Philippines, trade liberalisation appears to have benefited primarily the Manila area (Pernia and Quising 2003).

There is one exception to this general result. Sanguinetti and Volpe Martincus (2009) observe that employment in Argentine manufacturing sectors that were subject to larger tariff reductions in the 1985-1994 period tended to grow disproportionately in regions far away from the historical heart of manufacturing activity in and around Buenos Aires (which also happens to be the country's main ocean port). No significant effect is found for distance from Sao Paulo, which suggests that the observed dispersion away from the Argentine capital was not due to relocation close to regions bordering Brazil or Uruguay. These results certainly suggest that caution be applied in generalising the within-country effects from trade liberalisation; and the Argentine experience might merit further analysis, if possible spanning a longer time period and instrumenting for industry-level tariff changes. ${ }^{17}$

Moreover, if the best access to the foreign markets happens to be enjoyed by previously lagging regions, then the available evidence suggests that trade openness favours spatial convergence. One example is West Germany, whose border cities with East Germany experienced significantly slower population growth during the post-war period of German division, suggesting that the suppression of trade with Eastern Europe implied divergence of population trends across West German cities (Redding and Sturm 2008) A similar example is provided by Austria, whose previously relatively disadvantaged eastern border regions experienced significant boosts to both wages and employment subsequent to the fall of the Iron Curtain in 1990 (Brülhart et al. 2010).

In sum, and at the risk of some over-generalisation, the story implied by the within-country studies of regional adjustment to trade liberalisation is quite simple. Regions with better access to foreign markets benefit. If, previous to trade liberalisation, these were lagging regions, then liberalisation entails spatial convergence. If, however, the regions with the best access to foreign markets have been the most advanced regions already prior to trade liberalisation, then the opening of trade will bring about spatial divergence. ${ }^{18}$

\footnotetext{
16 Consistent with Henderson and Kuncoro's (1996) results, Sjöberg and Sjöholm (2004) calculate that Indonesian firms engaged in international trade are more spatially concentrated than non-trading firms, and that the spatial concentration of trading firms grew more strongly over the 1980-1996 period than that of non-trading firms.

17 One conceivable reverse-causality story is that industries concentrated around the capital city were more successful in lobbying against tariff cuts. The fact that Volpe (2010) finds a different result for Brazil, where trade liberalisation in the 1990s appears to have been associated with a significant shift of industry towards the Argentine border, makes the findings for Argentina stand out even more.

18 This effect does not seem to be confined to modern-day manufacturing trade. Atsumi (2011) reports how, subsequent to an abrupt opening to international trade by Japan in 1859, population shifted towards eastern Japan (with the new export gateway Tokyo) from western Japan (with the old capital Kyoto), and that this coincided with the west-east relocation of the main export industry (silk fabrics).
} 


\subsection{The European experience}

This survey would not be complete without consideration of the debate on the regional effects of European integration. Empirical research documents that EU integration over the last half-century has been associated with convergence across countries and divergence within countries (e.g. Baldwin and Wyplosz 2006; Rodriguez-Pose and Gill 2006; Melchior 2008b). This is mirrored to some extent by trends in spatial concentration of individual sectors, for which Brülhart and Traeger (2005), using decompositions of entropy indices, document an increase in the share of within-country concentration in the 1990s. Brülhart (2001) shows that industries that were strongly affected by the liberalisation measures under the EU's Single Market programme saw a particularly pronounced increase in spatial concentration after the launch of this programme in the early 1990s-liberalization thus appears to have favoured sectoral clustering. In Central and Eastern European countries, transition to market-based systems and integration into the EU have been accompanied by increasing regional inequalities, due mainly to further economic concentration of service sectors (Brülhart 2006) in capital cities (Melchior 2009), from an already very high level of urban primacy (Brülhart and Koenig 2006).

The parallel evolution of EU integration and intra-national spatial inequalities certainly suggests that market opening is no overwhelming force for regional convergence, but it should probably not be interpreted as causal evidence that trade in fact promotes regional divergence. Too many changes, both political and technological, have been occurring simultaneously with the deepening and widening of the EU's Single Market for researchers to attribute everything to this policy project. Solid causal evidence on the spatial effect of European integration remains elusive.

An interesting approach to this challenge is been taken by Melchior (2008a). He sets up a one-factor-one-sector monopolistic competition model over a map of nine countries and 90 regions in a grid pattern that resembles the geography of Europe. Changes in trade costs affect the relative market access of regions and therefore the wages they can afford to pay in equilibrium. This allows for the simulation of a number of liberalisation scenarios. The general pattern that emerges is that, other things equal, regions close to the frontier along which trade costs are reduced benefit more in terms of real-wage growth than regions far from that frontier. This again could imply convergence or divergence, depending on whether the border regions start from a lower or higher base than the interior regions. An exception to this pattern is found for scenarios where some interior region has "hub" status, in the sense that it enjoys lower trade costs to foreign markets than the geographically closer border regions. In that case, trade liberalisation tends to raise real wages in the hub region and increase inequality in the concerned country. Melchior's (2008a) simulations thus neatly encompass the main regularities found in the relevant theoretical and empirical literatures to date. 


\section{Conclusions}

This paper surveys the literature on the implications of trade liberalisation for intranational economic geographies. Three results stand out.

First, when regions are assumed to be symmetric, then neither urban systems models nor new economic geography models imply a robust prediction on the impact of trade openness on regional inequality. Whether trade promotes convergence or divergence depends on subtle modelling choices among which it is impossible to adjudicate a priori. The variety of theoretical predictions in fact shows that the question whether trade promotes intra-national spatial convergence or divergence is posed in overly general terms.

Second, empirical evidence mirrors the theoretical indeterminacy: a majority of cross-country studies find no significant effect of openness on urban concentration or overall regional inequality. The claim made in the passage of 2009 World Development Report cited in the Introduction, whereby openness "makes subnational disparities in income larger" (World Bank 2008, p. 12), therefore appears too strong and general in light of the existing scientific literature.

Third, the available models predict that, other things equal, regions with inherently less costly access to foreign markets, such as border or port regions, stand to reap the largest gains from trade liberalisation. This prediction is confirmed by the available evidence. Whether trade liberalisation raises or lowers regional inequality depends on each country's specific geography. The authors of the 2009 World Development Report therefore stand on firmer ground when proposing that "(n)ot all parts of a country are suited for accessing world markets, and coastal and economically dense places do better" (World Bank 2008, p. 12).

Intra-national geography is only partly shaped by nature. Port locations and navigable rivers are evident examples of natural features that facilitate access to distant markets. In modern economies, however, market access is shaped to an ever larger extent by man-made infrastructure, including roads, railway links, airports and telecommunication networks, as well as by the efficiency with which these networks are operated and by institutional factors affecting trade. The finding that regions with better access to foreign markets tend to reap the biggest gains from foreign trade logically implies that governments that seek to spread the gains from trade equally across their territories should seek to enhance the access of all domestic regions to foreign markets by removing market inefficiencies in the provision of internal transport and communication services and by investing in transport and telecommunications networks. ${ }^{19}$

This overview of the current literature points towards some potentially fruitful directions for future research. On the theoretical side, it could be useful to model the differential impacts of reductions in trade costs that are independent of distance (such as multilateral tariff cuts) and reductions in trade costs that are proportional to distance (such as falling transport costs). The relative importance of different

\footnotetext{
19 An important caveat to this conclusion is that, with regional differences in dimensions other than market access, improved intra-national trade infrastructure can have a dampening effect on economic activity in the less productive regions (Martin and Rogers 1995).
} 
regions' intra-national accessibility could in some instances depend on the nature of external trade liberalisation. For empirical work, there surely exists further scope for attempting explicitly causal estimation of the impact of trade on intra-national economic geographies, either through instrumentation or by exploiting quasiexperimental settings. Another promising avenue will be to refine the question and to search for differential spatial effects of openness in terms of wages and of employment, possibly at the industry level, and for interactions of such effects with exogenous features of geography, with endogenous agglomeration economies and with public policies.

Acknowledgments I thank participants at the seventh annual ELSNIT conference at the Kiel Institute as well as an anonymous referee for helpful comments, and the Inter-American Development Bank for commissioning this research. I am also grateful for financial support to the Swiss National Science Foundation (grant PDFMP1-123133 and NCCR “Trade Regulation”) and to the EU's Sixth Framework Programme ("Micro-Dyn" project).

\section{References}

Ades, A. F., \& Glaeser, E. L. (1995). Trade and circuses: Explaining urban giants. Quarterly Journal of Economics, 110(1), 195-227.

Alonso Villar, O. (1999). Spatial distribution of production and international trade: A note. Regional Science and Urban Economics, 29(3), 371-380.

Alonso Villar, O. (2001). Large metropolises in the third world: An explanation. Urban Studies, 38(8), 1359-1371.

Atsumi, T. (2011). Silk, regional rivalry, and the impact of the port openings in nineteenth century Japan. Journal of the Japanese and International Economies (forthcoming).

Baldwin, R. E., Forslid, R., Martin, P., Ottaviano, G. I. P., \& Robert-Nicoud, F. (2003). Economic geography and public policy. Princeton: Princeton University Press.

Baldwin, R. E., \& Wyplosz, C. (2006). The economics of European integration (2nd edn.). London: McGraw-Hill.

Behrens, K., Gaigné, C., Ottaviano, G. I. P., \& Thisse, J. F. (2006). How density economies in international transportation link the internal geography of trading partners. Journal of Urban Economics, 60(2), 248-263.

Behrens, K., Gaigné, C., Ottaviano, G. I. P., \& Thisse, J. F. (2007). Countries, regions and trade: On the welfare impacts of economic integration. European Economic Review, 51(5), 1277-1301.

Bertinelli, L., \& Black, D. (2004). Urbanization and growth. Journal of Urban Economics, 56, 80-96.

Brülhart, M. (2001). Evolving geographical concentration of European manufacturing industries. Weltwirtschaftliches Archiv/Review of World Economics, 137(2), 215-243.

Brülhart, M. (2006). The fading attraction of central regions: An empirical note on core-periphery gradients in Western Europe. Spatial Economic Analysis, 1(2), 227-235.

Brülhart, M., Carrère, C., \& Trionfetti, F. (2010). How wages and employment adjust to trade liberalisation: Quasi-experimental evidence from Austria. Mimeo, University of Lausanne.

Brülhart, M., Crozet, M., \& Koenig, P. (2004). Enlargement and the EU periphery: The impact of changing market potential. World Economy, 27(6), 853-875.

Brülhart, M., \& Koenig, P. (2006). New economic geography meets COMECON: Regional wages and industry location in Central Europe. Economics of Transition, 14(2), 245-267.

Brülhart, M., \& Sbergami, F. (2008). Agglomeration and growth: Empirical evidence. Journal of Urban Economics, 65(1), 48-63.

Brülhart, M., \& Traeger, R. (2005). An account of geographic concentration patterns in Europe. Regional Science and Urban Economics, 35(6), 597-624.

Chiquiar, D. (2005). Why Mexico's regional income convergence broke down. Journal of Development Economics, 77(1), 257-275. 
Chiquiar, D. (2008). Globalization, regional wage differentials and the Stolper-Samuelson theorem: Evidence from Mexico. Journal of International Economics, 74(1), 70-93.

Crozet, M., \& Koenig, P. (2004). EU enlargement and the internal geography of countries. Journal of Comparative Economics, 32(2), 265-278.

Duranton, G. (2008). From cities to productivity and growth in developing countries. Canadian Journal of Economics, 41(3), 689-736.

Egger, P., Huber, P., \& Pfaffermayr, M. (2005). A note on export openness and regional wage disparity in Central and Eastern Europe. Annals of Regional Science, 39(1), 63-71.

Faber, B. (2007). Towards the spatial patterns of sectoral adjustments to trade liberalisation: The case of NAFTA in Mexico. Growth and Change, 38(4), 567-594.

Fujita, M., Krugman, P., \& Venables, A. (1999). The spatial economy: Cities, regions and international trade. Cambridge, MA: MIT Press.

Gonzalez Rivas, M. (2007). The effects of trade openness on regional inequality in Mexico. Annals of Regional Science, 41(3), 545-561.

Haaparanta, P. (1998). Regional concentration, trade, and welfare. Regional Science and Urban Economics, 28(4), 445-463.

Hanson, G. H. (1997). Increasing returns, trade and the regional structure of wages. Economic Journal, 107(440), 113-133.

Hanson, G. H. (1998). Regional adjustment to trade liberalisation. Regional Science and Urban Economics, 28(4), 419-444.

Hanson, G. H. (2001). US-Mexico integration and regional economies: Evidence from border-city pairs. Journal of Urban Economics, 50(2), 259-287.

Henderson, J. V. (1974). The sizes and types of cities. American Economic Review, 64(4), 640-656.

Henderson, J. V. (1982). Systems of cities in closed and open economies. Regional Science and Urban Economics, 12(3), 325-350.

Henderson, J. V. (1987). General equilibrium modeling of systems of cities. In E. S. Mills (Ed.), Handbook of regional and urban economics (Vol. 2, pp. 927-956). Amsterdam: Elsevier.

Henderson, J. V. (1996). Ways to think about urban concentration: Neoclassical urban systems versus the new economic geography. International Regional Science Review, 19(1-2), 31-36.

Henderson, J. V. (2000). The effects of urban concentration on economic growth. (NBER Working Paper \#7503).

Henderson, J. V. (2003). The urbanization process and economic growth: The so-what question. Journal of Economic Growth, 8(1), 47-71.

Henderson, J. V., \& Kuncoro, A. (1996). Industrial centralization in Indonesia. World Bank Economic Review, 10(3), 513-540.

Junius, K. (1999). Primacy and economic development: Bell shaped or parallel growth of cities? Journal of Economic Development, 24(1), 1-22.

Kanbur, R., \& Zhang, X. (2005). Fifty years of regional inequality in China: A journey through central planning, reform and openness. Review of Development Economics, 9(1), 87-106.

Krugman, P. (1991). Increasing returns and economic geography. Journal of Political Economy, 99(3), 483-499.

Krugman, P., \& Livas Elizondo, R. (1996). Trade policy and the third world metropolis. Journal of Development Economics, 49(1), 137-150.

Mansori, K. S. (2003). The geographic effects of trade liberalization with increasing returns in transportation. Journal of Regional Science, 43(2), 249-268.

Martin, P., \& Rogers, C. A. (1995). Industrial location and public infrastructure. Journal of International Economics, 39(3-4), 335-351.

Melchior, A. (2008a). European integration and domestic regions: A numerical simulation analysis. (Working Paper). Warsaw: CASE Center for Economic and Social Research.

Melchior, A. (2008b). Regional inequality and convergence in Europe, 1995-2005. (Working Paper). Warsaw: CASE Center for Economic and Social Research.

Melchior, A. (2009). East-West integration and the economic geography of Europe. (Working Paper). Warsaw: CASE Center for Economic and Social Research.

Monfort, P., \& Nicolini, R. (2000). Regional convergence and international integration. Journal of Urban Economics, 48(2), 286-306.

Monfort, P., \& van Ypersele, T. (2003). Integration, regional agglomeration and international trade. (CEPR Discussion Paper \#3752). 
Moomaw, R. L., \& Alwosabi, M. A. (2004). An empirical analysis of competing explanations of urban primacy evidence from Asia and the Americas. Annals of Regional Science, 38(1), 149-171.

Moomaw, R. L., \& Shatter, A. M. (1996). Urbanization and economic development: A bias toward large cities? Journal of Urban Economics, 40(1), 13-37.

Nitsch, V. (2006). Trade openness and urban concentration: New evidence. Journal of Economic Integration, 21(2), 340-362.

Ottaviano, G. I. P., Tabuchi, T., \& Thisse, J.-F. (2002). Agglomeration and trade revisited. International Economic Review, 43(2), 409-436.

Paluzie, E. (2001). Trade policies and regional inequalities. Papers in Regional Science, 80(1), 67-85.

Pernia, E. M., \& Quising, P. F. (2003). Trade openness and regional development in a developing country. Annals of Regional Science, 37(3), 391-406.

Pflüger, M. (2004). A simple, analytically solvable, Chamberlinian agglomeration model. Regional Science and Urban Economics, 34(5), 565-573.

Ramcharan, R. (2009). Why an economic core: Domestic transport costs. Journal of Economic Geography, 9(4), 559-581.

Rauch, J. E. (1989). Increasing returns to scale and the pattern of trade. Journal of International Economics, 26(3-4), 359-369.

Rauch, J. E. (1991). Comparative advantage, geographic advantage and the volume of trade. Economic Journal, 101(408), 1230-1244.

Redding, S., \& Sturm, D. (2008). The costs of remoteness: Evidence from German division and reunification. American Economic Review, 98(5), 1766-1797.

Rodriguez-Pose, A., \& Gill, N. (2006). How does trade affect regional disparities? World Development, 34(7), 1201-1222.

Rodriguez-Pose, A., \& Sanchez-Reaza, J. (2005). Economic polarization through trade: Trade liberalization and regional growth in Mexico. In A. J. Venables \& R. Kanbur (Eds.), Spatial inequality and development. Oxford, UK: Oxford University Press.

Rosen, K. T., \& Resnick, M. (1980). The size distribution of cities: An examination of the Pareto law of primacy. Journal of Urban Economics, 8(2), 165-186.

Sanguinetti, P., \& Volpe Martincus, C. (2009). Tariffs and manufacturing location in Argentina. Regional Science and Urban Economics, 39(2), 155-167.

Sjöberg, Ö., \& Sjöholm, F. (2004). Trade liberalization and the geography of production: Agglomeration, concentration, and dispersal in Indonesia's manufacturing industry. Economic Geography, 80(3), 287-310.

Volpe Martincus, C. (2010). Spatial effects of trade policy: Evidence from Brazil. Journal of Regional Science, 50(2), 541-569.

World Bank. (2008). World development report 2009: Reshaping economic geography. Washington, DC. 